\title{
Practical C-P bond formation via heterogeneous photoredox and nickel synergetic catalysis
}

\author{
Ernest Koranteng a,t, Yi-Yin Liu a,t, Si-Yue Liu a, Qiang-Xian Wu a, Liang-Qiu Lu a,b,*, Wen-Jing Xiao a \\ a CCNU-uOttawa Joint Research Centre, Hubei International Scientific and Technological Cooperation Base of Pesticide and Green Synthesis, Key Labora- \\ tory of Pesticides \& Chemical Biology Ministry of Education, College of Chemistry, Central China Normal University, Wuhan 430079, Hubei, China \\ b State Key Laboratory for Oxo Synthesis and Selective Oxidation, Lanzhou Institute of Chemical Physics (LICP), Chinese Academy of Sciences, Lanzhou \\ 730000, Gansu, China
}

\section{A R T I C L E I N F}

\section{Article history:}

Received 19 April 2019

Accepted 11 May 2019

Published 5 December 2019

\section{Keywords:}

Photoredox catalysis

Nickel catalysis

Construction of carbon-phosphorus

bond

Heterogeneous

\begin{abstract}
A B S T R A C T
An efficient C-P bond formation reaction was developed by virtue of the synergetic catalysis strategy by merging heterogeneous photocatalysis and nickel catalysis. This platform utilizing cadmium sulfide semiconductors as heterogeneous photocatalysts and nickel complexes as transition metal catalysts provided a variety of organophosphorus compounds from readily available aryl and vinyl halides, as well as aryl triflates, with generally a good-to-excellent reaction efficiency (31 examples, 46\%-98\% yields). The current protocol features mild reaction conditions, a broad substrate scope, recyclability of photocatalysts, and inexpensive catalysts, thus defining the practical and economic proprieties of the present catalyst system.
\end{abstract}

(C) 2019, Dalian Institute of Chemical Physics, Chinese Academy of Sciences. Published by Elsevier B.V. All rights reserved.
Given the fundamental significance of organophosphorus compounds ranging from synthetic, pharmaceutical, and agricultural chemistries to materials and life sciences, the construction of $\mathrm{C}-\mathrm{P}$ bonds has long been an important task for generations of synthetic chemists [1-7]. Since the pioneering work from Hirao et al., who developed the palladium-catalyzed phosphonation of aryl iodides or bromides in the 1980s [8-10], transition-metal-catalyzed C-P couplings have been among the most reliable tools for synthesizing organophosphorus molecules. In recent decades, many elegant protocols using aryl halides, boronic acids, triflates, sulfonates, and other precursors as coupling partners have been developed for this purpose [11-16]. However, the requirement of expensive and air-sensitive ligands and oxidants and the harsh reaction conditions in these transition metal catalysis systems usually resulted in a limited substrate scope and poor functional group tolerance, as well as high synthetic costs. Consequently, the development of efficient and economical methods for $\mathrm{C}-\mathrm{P}$ bond formation is still highly desirable.

Recently, a number of impressive approaches have been reported for constructing C-P bonds following the advent of visible photoredox catalysis as a powerful and ecofriendly synthetic tool [17-32]. Particularly, the strategy of synergistic catalysis by merging visible-light photoredox catalysis [33-35] with organometallic catalysis has provided several attractive accesses to organophosphorus molecules [29-32]. For exam-

\footnotetext{
* Corresponding author. Tel/Fax: +86-27-67862041; E-mail: luliangqiu@mail.ccnu.edu.cn

† Contributed equally to this work.

We are grateful to the National Science Foundation of China (21822103, 21820102003, 21772052, 21772053, 21572074, 21472057), the Program of Introducing Talents of Discipline to Universities of China (111 Program, B17019), the Natural Science Foundation of Hubei Province (2017AHB047), and the International Joint Research Center for Intelligent Biosensing Technology and Health for support of this research. DOI: S1872-2067(19)63379-6 | http://www.sciencedirect.com/science/journal/18722067 | Chin. J. Catal., Vol. 40, No. 12, December 2019
} 
ple, in 2015, Toste et al. [29] disclosed an elegant C-P coupling reaction of aryldiazonium salts and $H$-phosphonates in the presence of gold catalysts and ruthenium-based photocatalysts. In the same year, a dual catalytic $\mathrm{C}\left(s p^{2}\right)-\mathrm{P}$ formation reaction of diphenylphosphine oxides with aryl iodides by using nickel catalysts and ruthenium-based photosensitizers was reported [30]. In 2017, Lei et al. [31] reported a visible-light-induced oxidant-free oxidative phosphonylation of a $\mathrm{C}\left(s p^{2}\right)-\mathrm{H}$ bond of arenes via a dual photoredox and cobalt catalysis. Despite these important advances in the field of photocatalytic C-P bond formation, regardless of whether single photoredox catalysis or the synergistic photoredox and organometallic catalysis is used, homogeneous photocatalysts, including ruthenium or iridium complexes and organic dyes, are widely applied. This leads to the problem of the inability to separate, recover, and reuse compared with heterogeneous photocatalysts (Fig. 1(a)) [36-44]. In this work, because of continuing interest in visible-light photocatalysis [45-50], this C-P formation reaction is updated by the joint use of $\mathrm{Ni}$ catalysts and heterogeneous cadmium sulfide (CdS, 2.4-eV bandgap) photocatalysts (Fig. 1(b)) [51]. Compared with previous endeavors, this protocol should attract wide interest from the synthetic community because of the recyclable photocatalysts, a less expensive catalyst system, and a broad substrate scope.

The study began with ethyl 4-bromobenzoate and diphenylphosphine oxide as substrates. Exposure of these two chemicals in $\mathrm{CH}_{3} \mathrm{CN}$ to blue light-emitting diodes (LEDs) in the presence of 20 -mol\% CdS, 5-mol\% $\mathrm{NiCl}_{2} \cdot 6 \mathrm{H}_{2} \mathrm{O}$, 5-mol\% dtbbpy, and 2.0 equiv. DBU under an $\mathrm{Ar}$ atmosphere at $55^{\circ} \mathrm{C}$ resulted in the desired product 3aa in 21\% yield after $24 \mathrm{~h}$. Because of this result, different parameters were evaluated to improve the reaction efficiency. First, it was found that organic base $\mathrm{Et}_{3} \mathrm{~N}$ gave the best yield of the product (Table 1, entry $4,80 \%$ yield) among all the screened bases. Second, after other reaction media were screened, DMA stood out as the optimal one (Table 1, entry 6), and the best substrate ratio of $\mathbf{1 a}$ to $\mathbf{2 a}$ was 1:2 (Table S2). Third, the reaction, when performed at room temperature, gave a low reaction efficiency (Table 1, entry 10). Finally, control experiments revealed that $\mathrm{Ni}, \mathrm{CdS}$, base, and light were all essential components for obtaining high efficiency (Table S3).

After the optimized conditions were established, the gener-

a) Previous work: C-P bond formation via homogenous photocatalysis

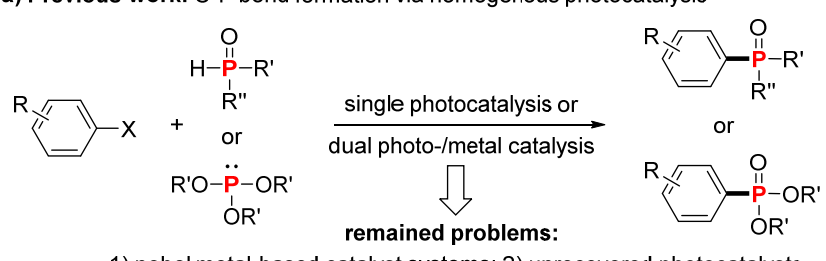

1) nobel metal-based catalyst systems; 2 ) unrecovered photocatalysts

b) This work: C-P bond formation via heterogenous photocatalysis

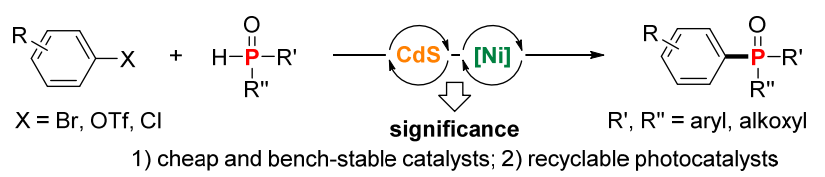

Fig. 1. Visible-light photocatalytic C-P bond formation.
Table 1

Condition optimization a.

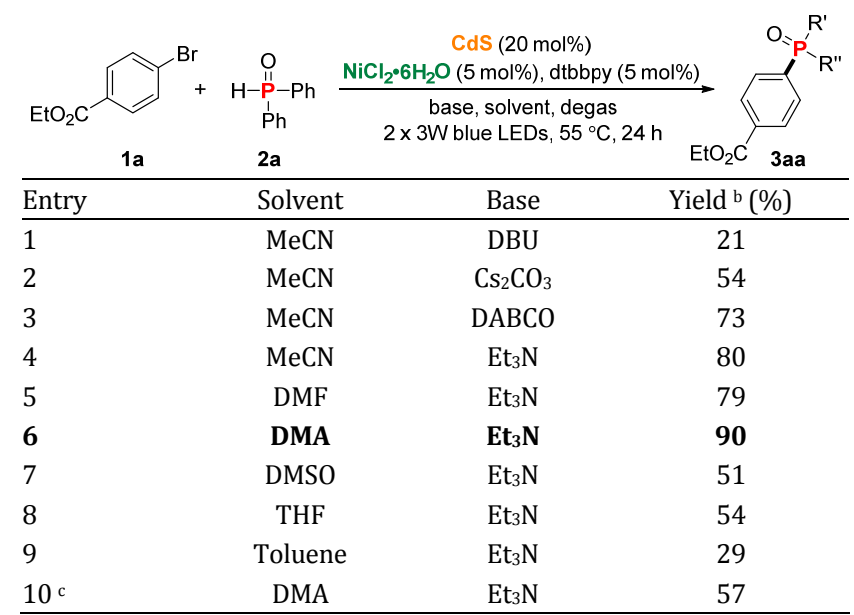

${ }^{a}$ Reaction conditions: 1a $(1.0 \mathrm{mmol}), \mathbf{2 a}(1.5 \mathrm{mmol}, 1.5$ equiv), base $(2.0$ mmol, 2.0 equiv.), $\mathrm{NiCl}_{2} \bullet 6 \mathrm{H}_{2} \mathrm{O}(0.05 \mathrm{mmol}, 5 \mathrm{~mol} \%)$, dtbbpy $(0.05 \mathrm{mmol}$, $5 \mathrm{~mol} \%)$, CdS (0.2 mmol, $20 \mathrm{~mol} \%)$, and solvent $(3.0 \mathrm{~mL})$ under irradiation by $2 \times 3 \mathrm{~W}$ blue LEDs. ${ }^{\mathrm{b}}$ Isolated yield of 3aa. 'Room temperature for $24 \mathrm{~h}$. LEDs, light-emitting diodes; DBU, 1,5-diazabicyclo[4.3.0]non5-ene; dtbbpy, 4,4'-di-tert-butyl-2,2'-bipyridine; DMA, dimethylacetamide.

ality of this catalyst system for the C-P coupling was then investigated. Different aryl bromides bearing a variety of functional groups can be utilized in this protocol to deliver the coupled product with a good-to-excellent yield (Scheme 1). For instance, aryl bromides containing electron-withdrawing groups, such as ester, ketone, nitrile, trifluoromethyl, and fluoride, at the para- or meta-position were adequate coupling

\section{Scheme 1}

Substrate scope of aryl bromides.
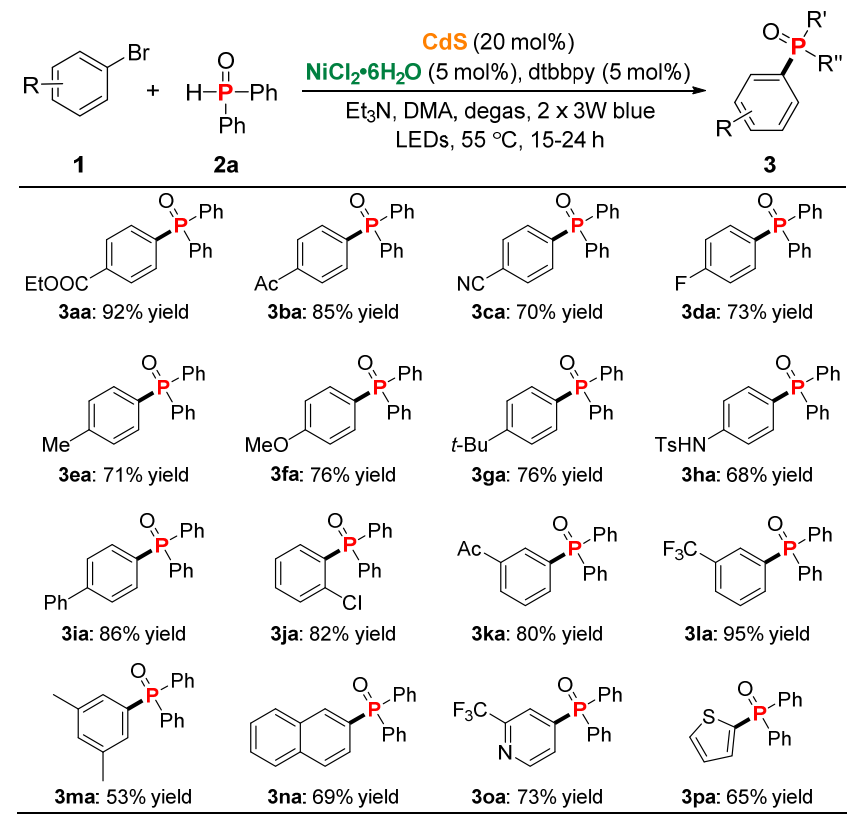

Reaction conditions: $\mathbf{1}(0.5 \mathrm{mmol}), \mathbf{2 a}(1.0 \mathrm{mmol}, 2.0$ equiv.), base $(1.0$ mmol, 2.0 equiv) $\mathrm{NiCl}_{2} \bullet 6 \mathrm{H}_{2} \mathrm{O}(0.025 \mathrm{mmol}, 5 \mathrm{~mol} \%)$, dtbbpy $(0.025$ $\mathrm{mmol}, 5 \mathrm{~mol} \%)$, CdS (0.1 mmol, $20 \mathrm{~mol} \%)$, and DMA (2.0 $\mathrm{mL})$ under irradiation by $2-\times 3$-W blue LEDs; isolated yields. 
Scheme 2

Representative results of aryl chlorides and triflates.

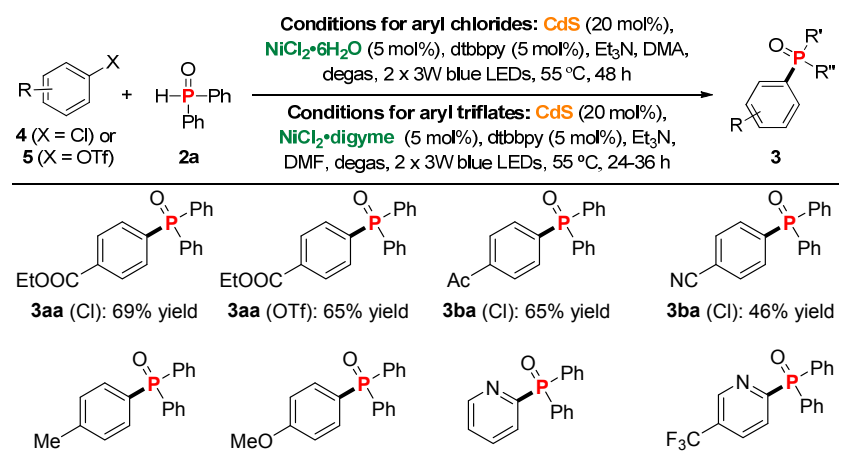

3ea (OTf): $54 \%$ yield 3 3fa (OTf): $49 \%$ yield $\quad$ 3qa (Cl): $75 \%$ yield $\quad 3$ ra (Cl): $81 \%$ yield Reaction conditions: 4 or 5 ( $0.5 \mathrm{mmol}), 2$ a (1.0 mmol, 2.0 equiv), $\mathrm{NEt}_{3}$ (1.0 mmol, 2.0 equiv.), $\mathrm{Ni}(\mathrm{II})$ salt $(0.025 \mathrm{mmol}, 5 \mathrm{~mol} \%)$, dtbbpy $(0.025$ mmol, $5 \mathrm{~mol} \%)$, CdS (0.1 mmol, $20 \mathrm{~mol} \%)$, and DMA or DMF (2.0 mL) under irradiation by $2-\times 3-W$ blue LEDs; isolated yields.

partners (3aa-3da, 3ka, and 3la: 70\%-95\% yields). With the existence of a competing chlorine group, the reaction exhibits good chemoselectivity, giving the C-P coupled product a good yield (3ja: $82 \%$ yield). Furthermore, aryl bromides bearing electron-donating groups, such as methyl, methoxyl, tert-butyl, protected amine, and phenyl, as well as 3,5-dimethylphenyl and fused rings, can readily participate in this coupling reaction (3ea-3ia, 3ma, and 3na: 53\%-86\% yields). Moreover, heteroaryl bromides were also compatible in this coupling system and converted to the corresponding products in good yields (3oa: 73\% yield; 3pa: 65\% yield).

Next, a representative set of aryl chlorides and triflates was examined as possible partners for the C-P coupling. As exemplified in Scheme 2, because of the lower reactivity of aryl chlorides compared with aryl bromides, long reaction times were required for aryl chlorides, and, generally, decreased yields were observed for aryl chlorides and triflates (from chlorides 4: 46\%-69\% yields; from triflates 5: 49\%-65\% yields). However, the C-P coupling reactions of 2-chloropyridines $\mathbf{4 q}$ and $\mathbf{4 r}$ can produce the corresponding products in high yields (3qa: $75 \%$ yield; 3ra: $81 \%$ yield).

Then, the scope of the phosphine oxide substrate was evaluated. As shown in Scheme 3, a series of P-H compounds, including $H$-phosphinates, $H$-phosphonates, and secondary phosphine oxides, with varied electronic and steric properties, can be well applied as efficient substrates, affording the corresponding organophosphorus products with excellent levels of efficiency (3ab-3ae: 90\%-98\% yields). However, aliphatic secondary phosphine oxides failed to participate in this transformation at the current stage for unknown reasons.

To demonstrate the practicality of this protocol, the coupling reaction of 1a and 2a was performed on a gram scale (10 mmol) under the standard reaction conditions, finally affording product 3aa (3.01 g) in an excellent yield (Scheme 4, Eq. (1)). Moreover, considering the importance of vinylphosphine motifs in polymer science and in the synthesis of heterocycles [52-56], whether vinyl bromides could be used as suitable coupling partners for this coupling was considered. Alkyl, aryl,
Scheme 3

Substrate scope of phosphine oxides.

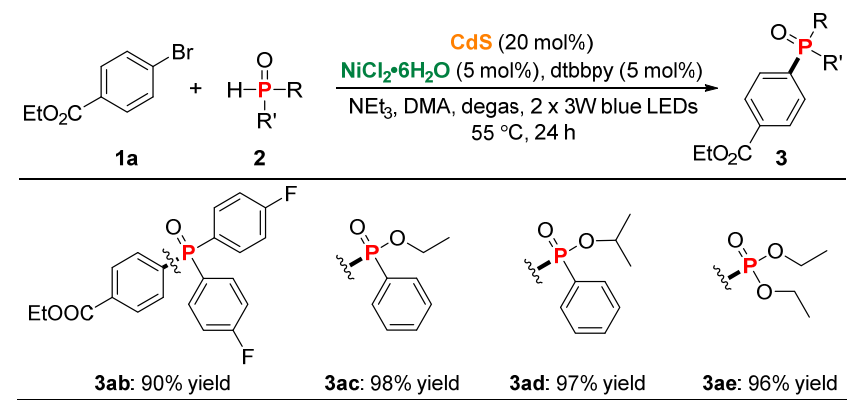

Reaction conditions: 1a (0.5 mmol), 2 (1.0 mmol, 2.0 equiv.), $\mathrm{NEt}_{3}$ (1.0 mmol, 2.0 equiv), $\mathrm{NiCl}_{2} .6 \mathrm{H}_{2} \mathrm{O}(0.025 \mathrm{mmol}, 5 \mathrm{~mol} \%)$, dtbbpy $(0.025$ mmol, $5 \mathrm{~mol} \%)$, CdS (0.1 mmol, $20 \mathrm{~mol} \%)$, and DMA (2.0 mL) under irradiation by $2-\times 3-\mathrm{W}$ blue LEDs; yield after isolation by column chromatography.

and diaryl-substituted vinyl bromides were successfully converted into alkenyl phosphine oxides in good yields under the standard dual catalysis conditions (Scheme 4, Eq. (2): 7aa-7ca, 67\%-93\% yields). In addition, it was found that the CdS photocatalyst can be easily recovered through a simple filtration and washing with DMA after each run. Subsequently, substrates 1a and 2a, together with a Ni salt, a ligand, $\mathrm{Et}_{3} \mathrm{~N}$, and DMA, were added for a new run. As shown in Fig. 2, the catalyst could be recycled at least five times without any significant loss of efficiency (note: a control experiment revealed that no desired product is observed in the absence of a Ni catalyst and the ligand after each run).

Furthermore, an attempt was made to gain insight into the reaction mechanism. When 2.0 equiv. of the radical scavenger 2,2,6,6-tetramethylpiperidine-1-oxyl (TEMPO) was added to the reaction under standard conditions, the formation of 3aa was completely inhibited, and the phosphine-TEMPO adduct was detected by HRMS, which indicated the involvement of radicals in this reaction. Based on this result and previous reports [30,32-44,51], a plausible reaction mechanism was proposed for the formation of the desired C-P bond (Fig. 3). Upon exposure to visible light, isomer $\mathbf{A}$ from substrate $\mathbf{2 a}$ was oxi-

\section{Scheme 4}

Gram-scale reaction and scope of vinyl bromides.

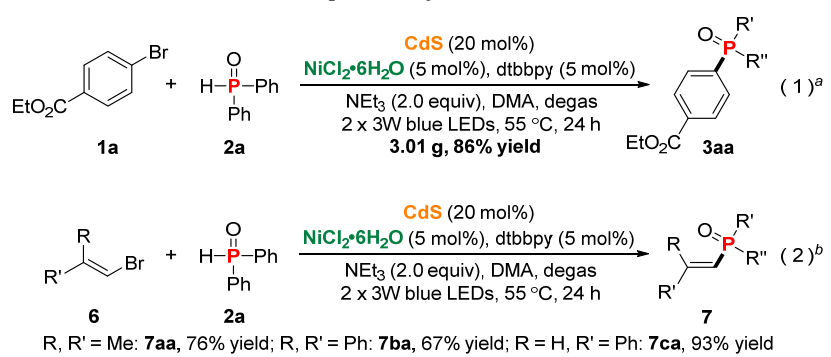

a Reaction conditions: $\mathrm{NiCl}_{2} \cdot 6 \mathrm{H}_{2} \mathrm{O}(0.5 \mathrm{mmol}, 0.12 \mathrm{~g})$, dtbbpy $(0.5 \mathrm{mmol}$, $0.13 \mathrm{~g}$ ), CdS (2.0 mmol, $0.29 \mathrm{~g}), 1 \mathrm{a}(10 \mathrm{mmol}, 1.6 \mathrm{~mL}), 2 \mathrm{a}(20 \mathrm{mmol}, 4.0$ g), $\mathrm{NEt}_{3}$ (20.0 mmol, 2.0 equiv.), and DMA (40.0 mL); isolated yield. beaction conditions: 6 ( $0.5 \mathrm{mmol}), 2 \mathrm{a}\left(1.0 \mathrm{mmol}, 2.0\right.$ equiv.), $\mathrm{NEt}_{3}$ (1.0 mmol, 2.0 equiv.), $\mathrm{NiCl}_{2} \bullet 6 \mathrm{H}_{2} \mathrm{O}(0.025 \mathrm{mmol}, 5 \mathrm{~mol} \%)$, dtbbpy (0.025 mmol, $5 \mathrm{~mol} \%)$, CdS (0.1 mmol, $20 \mathrm{~mol} \%)$, and DMA (2.0 $\mathrm{mL})$ under irradiation by $2 \times 3 \mathrm{~W}$ blue LEDs; isolated yield. 


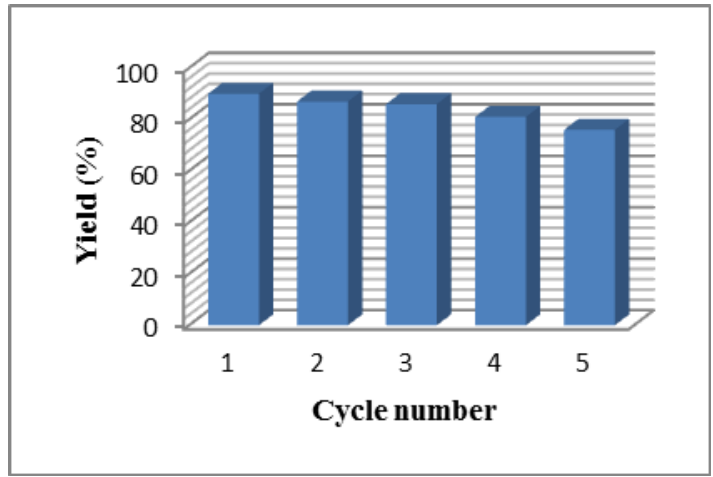

Fig. 2. Results of the recyclability test for the C-P bond formation via heterogeneous synergistic catalysis.

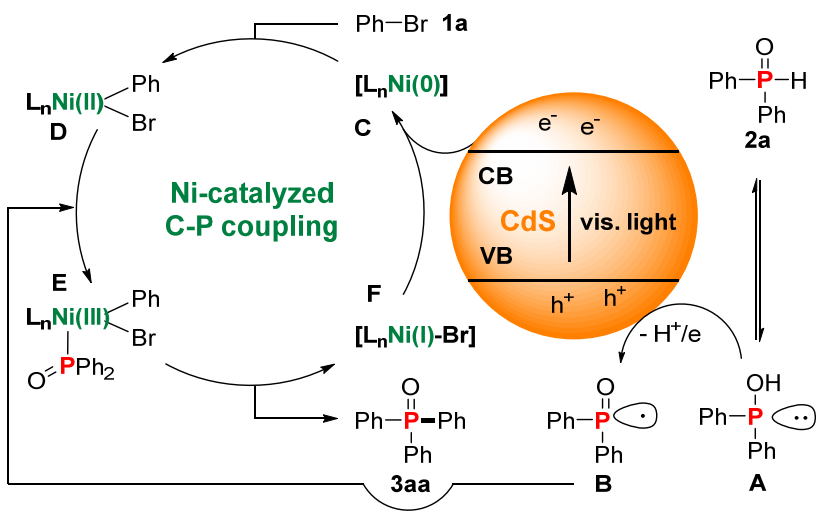

Fig. 3. Proposed mechanism.

dized by the excited CdS photocatalyst via injection of an electron into the conduction band of CdS. The formed radical-cation intermediate was subsequently deprotonated by a base to afford the P-centered radical $\mathbf{B}$. Concurrently, the oxidative additive of the aryl halide to $\mathrm{Ni}(0)$ catalyst $\mathrm{C}$ would deliver the electrophilic Ni(II) intermediate $\mathbf{D}$, which could rapidly capture the P-centered radical $\mathbf{B}$ to form the Ni(III) complex E, thereby setting the stage for $\mathrm{C}-\mathrm{P}$ bond-forming reductive elimination to afford the desired product 3aa. Finally, the interface of the two catalytic cycles ( $F \leftrightarrow \mathrm{CdS} \cdot$-) via single-electron transfer would regenerate the base state of $\mathrm{CdS}$ photocatalyst and the $\mathrm{Ni}(0)$ catalyst C. However, it was recognized that an alternative mechanism, where the generated P-centered radical is trapped by $\mathrm{Ni}^{0}$ species before oxidative addition, cannot be ruled out at this current stage.

In conclusion, a visible-light-induced heterogeneous $\mathrm{CdS} / \mathrm{Ni}$ synergistic catalysis was developed for efficiently constructing C-P bonds. This method employs readily available aryl and vinyl halides, as well as aryl triflates, to produce organophosphorus compounds with good-to-excellent yields. Notably, the recyclable photocatalyst and inexpensive catalyst system, together with a broad substrate scope and high functional group tolerance, make the updated $\mathrm{C}-\mathrm{P}$ bond formation protocol practical and attractive for synthetic chemists.

\section{Notes}

The authors declare no competing financial interest.

\section{Acknowledgment}

We are grateful to the National Science Foundation of China (21822103, 21820102003, 21772052, 21772053, 21572074, 21472057), the Program of Introducing Talents of Discipline to Universities of China (111 Program, B17019), the Natural Science Foundation of Hubei Province (2017AHB047), and the International Joint Research Center for Intelligent Biosensing Technology and Health for support of this research.

\section{References}

[1] L. D. Quin, A Guide to Organophosphorus Chemistry; Wiley Interscience, New York, 2000.

[2] P. J. Murphy, Organophosphorus Reagents, Oxford University Press, Oxford, U.K., 2004.

[3] T. Baumgartner, R. Reau, Chem. Rev., 2006, 106, 4681-4727.

[4] P. Guga, Curr. Top. Med. Chem., 2007, 7, 695-713.

[5] R. Martin, S. L. Buchwald, Acc. Chem. Res., 2008, 41, 1461-1473.

[6] C. S. Demmer, N. Krogsgaard-Larsen, L. Bunch, Chem. Rev., 2011, 111, 7981-800.

[7] G. P. Horsman, D. L. Zechel, Chem. Rev., 2017, 117, 5704-5783.

[8] T. Hirao, T. Masunaga, Y. Ohshiro, T. Agawa, Tetrahedron Lett., 1980, 21, 3595-3598.

[9] T. Hirao, T. Masunaga, Y. Ohshiro, T. Agawa, Synthesis, 1981, 56-57.

[10] T. Hirao, T. Masunaga, N. Yamada, Y. Ohshiro, T. Agawa, Bull. Chem. Soc. Jpn., 1982, 55, 909-913.

[11] J. L. Montchamp, Y. R. Dumond, J. Am. Chem. Soc., 2001, 123, 510-511.

[12] K. Muñiz, Angew. Chem. Int. Ed., 2009, 48, 9412-9423.

[13] T. Chen, J. S. Zhang, L. B. Han, Dalton Trans., 2016, 45, 1843-1849.

[14] D. Gelman, L. Jiang, S. L. Buchwald, Org. Lett., 2003, 5, 2315-2318.

[15] C. R. Shen, G. Q. Yang, W. B. Zhang, Org. Biomol. Chem., 2012, 10, 3500-3505.

[16] P. Xu, Z. Wu, N. Zhou, C. Zhu, Org. Lett., 2016, 18, 1143-1145.

[17] J. M. R. Narayanam, C. R. J. Stephenson, Chem. Soc. Rev., 2011, 40, 102-113.

[18] J. Xuan, W.-J. Xiao, Angew. Chem. Int. Ed., 2012, 51, 6828-6838.

[19] D. M. Schultz, T. P. Yoon, Science, 2014, 343, 985-993.

[20] C. K. Prier, D. A. Rankic, D. W. C. MacMillan, Chem. Rev., 2013, 113, 5322-5363.

[21] N. A. Romero, D. A. Nicewicz, Chem. Rev., 2016, 116, 10075-10166.

[22] L. Marzo, S. K. Pagire, O. Reiser, B. König, Angew. Chem. Int. Ed., 2018, 57, 10034-10072.

[23] K. Luo, W.-C. Yang, L. Wu, Asian J. Org. Chem., 2017, 6, 350-367.

[24] K. Luo, Y.-Z. Chen, L.-X. Chen, L. Wu, J. Org. Chem., 2016, 81, 4682-4689.

[25] P. Peng, L. Peng, G. Wang, F. Wang, Y. Luo, A. Lei, Org. Chem. Front., 2016, 3, 749-752.

[26] R. S. Shaikh, S. J. S. Düsel, B. König, ACS Catal., 2016, 6, 8410-8414.

[27] J. Yuan, W.-P. To, Z.-Y. Zhang, C.-D. Yue, S. Meng, J. Chen, Y. Liu, G.-A. Yu, C.-M. Che, Org Lett., 2018, 20, 7816-7820.

[28] H. Zeng, Q. Dou, C.-J. Li, Org Lett., 2019, 21, 1301-1305.

[29] Y. He, H. Wu, F. D. Toste, Chem. Sci., 2015, 6, 1194-1198.

[30] J. Xuan, T.-T. Zeng, J.-R. Chen, L.-Q. Lu, W.-J. Xiao, Chem. Eur. J., 2015, 21, 4962-4965.

[31] L. Niu, J. Liu, H. Yi, S. Wang, X.-A. Liang, A. K. Singh, C.-W. Chiang, A. Lei, ACS Catal., 2017, 7, 7412-7416.

[32] L-L. Liao, Y-Y. Gui, X-B. Zhang, G. Shen, H-D. Liu, W-J. Zhou, J. Li, 


\title{
Graphical Abstract
}

Chin. J. Catal., 2019, 40: 1841-1846 doi: S1872-2067(19)63379-6

Practical C-P bond formation via heterogeneous photoredox and nickel synergetic catalysis

Ernest Koranteng, Yi-Yin Liu, Si-Yue Liu, Qiang-Xian Wu, Liang-Qiu Lu *, Wen-Jing Xiao

Central China Normal University; Lanzhou Institute of Chemical Physics (LICP), Chinese Academy of Sciences

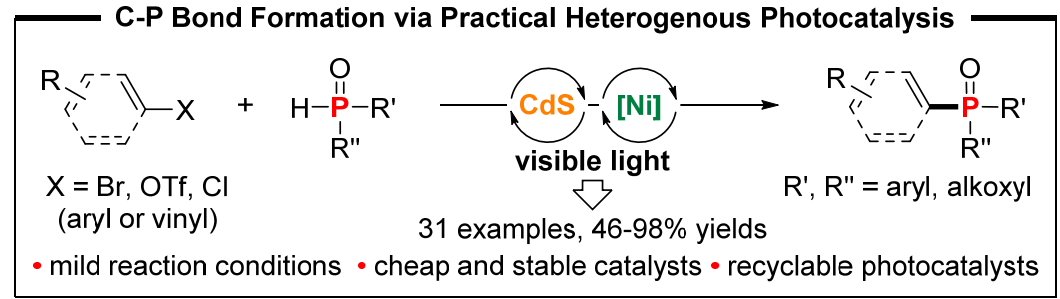

A carbon-phosphorus bond formation reaction was developed by merging heterogeneous photocatalysis and nickel catalysis. This protocol features mild reaction conditions, a broad substrate scope, recyclability of photocatalysts, and inexpensive catalysts, thus defining the practical and economic proprieties of the present catalyst system.

D-G. Yu, Org. Lett., 2017, 19, 3735-3738.

[33] M. N. Hopkinson, B. Sahoo, J.-L. Li, F. Glorius, Chem. Eur. J., 2014, 20, 3874-3886.

[34] K. L. Skubi, T. R. Blum, T. P. Yoon, Chem. Rev., 2016, 116, 10035-10074.

[35] J. Twilton, C. Le, P. Zhang, M. H. Shaw, R. W. Evans, D. W. C. MacMillan, Nat. Rev. Chem., 2017, 1, 0052.

[36] F. Wang, W. G. Wang, X. J. Wang, H. Y. Wang, C. H. Tung, L. Z. Wu, Angew. Chem. Int. Ed., 2011, 50, 3193-3197.

[37] S. Ma, J. Xie, J. Wen, K. He, X. Li, W. Liu, X. Zhang, Appl. Surf. Sci., 2017, 391, 580-591.

[38] J. Feng, H. Frei, Angew. Chem. Int. Ed., 2009, 48, 1841-1844.

[39] W. J. Youngblood, S. H. A. Lee, K. Maeda, T. E. Mallouk, Acc. Chem. Res., 2009, 42, 1966-1973.

[40] A. Kumar, A. G. Samuelson, Eur. J. Org. Chem., 2011, 951-959.

[41] U. P. Apfel, W. Weigand, Angew. Chem. Int. Ed., 2011, 50, 4262-4264.

[42] R. Lechner, B. König, Synthesis, 2010, 1712-1718.

[43] X. J. Lang, H. W. Ji, C. C. Chen, W. H. Ma, J. C. Zhao, Angew. Chem. Int. Ed., 2011, 50, 3934-3937.

[44] T. Mitkina, C. Stanglmair, W. Setzer, M. Gruber, H. Kischc, B. König,
Org. Biomol. Chem., 2012, 10, 3556-3561.

[45] J.-R. Chen, X.-Q. Hu, L.-Q. Lu, W.-J. Xiao, Acc. Chem. Res., 2016, 49, 1911-1923.

[46] W. Ding, L.-Q. Lu, Q.-Q. Zhou, Y. Wei, J.-R. Chen, W.-J. Xiao, J. Am. Chem. Soc., 2017, 139, 63-66.

[47] M.-M. Li, Y. Wei, J. Liu, H.-W. Chen, L.-Q. Lu, W.-J. Xiao, J. Am. Chem. Soc., 2017, 139, 14707-14713.

[48] Q.-Q. Zhou, D. Liu, W.-J. Xiao, L.-Q. Lu, Acta Chim. Sinica, 2017, 75, 110-114.

[49] Y. Wei, S. Liu, M.-M. Li, Y. Li, Y. Lan, L.-Q. Lu, W.-J. Xiao, J. Am. Chem. Soc., 2019, 141, 133-137.

[50] X. Jiang, M.-M. Zhang, W. Xiong, L.-Q. Lu, W.-J. Xiao, Angew. Chem. Int. Ed., 2019, 58, 2402-2406.

[51] Z. Chai, T.-T. Zeng, Q. Li, L.-Q. Lu, W.-J. Xiao, D. Xu, J. Am. Chem. Soc., 2016, 138, 10128-10131.

[52] T. Minami, J. Motoyoshiya, Synthesis, 1992, 4, 333-349.

[53] P. Adler, A. Fadel, N. Rabasso, Tetrahedron, 2014, 70, 4437-4456.

[54] X. Y. Jiao, W. G. Bentrude, J. Org. Chem., 2003, 68, 3303-3306.

[55] G. J. Schlichting, J. L. Horan, J. D. Jessop, S. E. Nelson, S. Seifert, Y. Yang, A. M. Herring, Macromolecules, 2012, 45, 3874-3882.

[56] Q. Wu, R. A. Weiss, Polymer, 2007, 48, 7558-7566.

\section{协同的非均相光氧化还原催化和镍催化构建碳磷键}

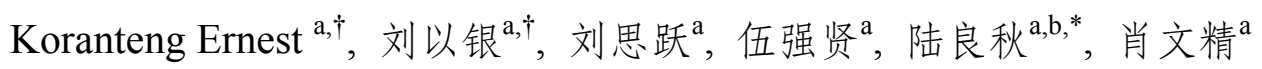 \\ a华中师范大学化学学院, 农药与化学生物学重点实验室, 华师-渥太华大学国际联合研究中心, 湖北武汉430079 \\ b 中国科学院兰州化学物理研究所, 羰基合成与选择氧化国家重点实验室, 甘肃兰州730000
}

摘要: 作为一类重要的功能有机分子, 有机膦化合物广泛用于医药、农药、材料以及生命科学等众多领域中. 因此, 实现 C-P键的高效、高选择性构建一直是合成化学家们的一项重要研究内容. 过渡金属催化的碳磷成键反应为有机磷化物的合 成提供了一个行之有效的方法, 芳基卤代物、硼酸、三氟磺酸酯等前体均可用于该偶联反应. 但是, 这些反应往往需要用 到价格昂贵、空气敏感的金属催化剂或配体以及当量的氧化试剂, 且反应条件苛刻. 为此, 人们迫切需要发展经济、高效、 条件温和且具有普适性的绿色合成方法来解决有机膦化合物合成领域的这一难点问题.

近年来, 可见光促进的光氧化还原催化因其绿色、环保的优点而受到越来越多合成化学家们的关注. 目前, 所使用的 光催化剂大多是基于贵金属钓、铱的金属有机络合物或一些有机染料分子. 相比于均相催化的有机光化学反应, 非均相催 
化过程在催化剂的稳定性与回收利用以及产物分离等方面具有明显的优势.

本文使用商业可得的半导体材料硫化镉作为非均相光催化剂, 金属镍复合物作为过渡金属催化剂, 实现了过渡金属与 光敏剂协同催化的碳磷成键反应. 该反应具有非常广的底物适用范围, 芳基氯代物、澳代物、三氟磺酸酯以及烯基溴代物 均能较好地参与该反应, 温和条件下高效地合成得到一系列有机磷化物. 将反应规模扩大至克级时, 我们发现反应效率几 乎不受影响, 且反应结束后过滤得到的光催化剂在循环5次后反应效果仍相近. 由此可见硫化镉/镍非均相催化体系在有机 膦化合物的光化学合成中的有效性和实用性. 此外, 我们还通过控制实验和自由基捕获实验以及相关文献, 提出了该反应 的可能机理.

关键词: 光氧化还原催化; 镍催化; 碳磷键构建; 非均相催化

收稿日期: 2019-04-19. 接受日期: 2019-05-11. 出版日期: 2019-12-05.

*通讯联系人. 电话/传真: (027)67862041; 电子信箱: luliangqiu@mail.ccnu.edu.cn

†共同第一作者.

基金来源：国家自然科学基金(21822103, 21820102003, 21772052, 21772053, 21572074, 21472057); 高等学校学科创新引智计划 (B17019); 湖北省自然科学基金(2017AHB047).

本文的电子版全文由Elsevier出版社在ScienceDirect上出版(http://www.sciencedirect.com/science/journal/18722067). 